\title{
Factors Promoting Innovation and Efficiency in the Construction Industry: A Comparative Study of New Zealand and Australia
}

\author{
Will Chancellor ${ }^{1}$, Malcolm Abbott ${ }^{2}$ and Chris Carson ${ }^{3}$ \\ ${ }^{1}$ Australian Burean of Statistics, 7th Floor, South Tower, 485 LaTrobe Street, Melbourne, Australia \\ ${ }^{2}$ Swinburne University of Technology, John Street, Hawthorn, Australia \\ ${ }^{3}$ UNITEC, Carrington Rd, Mount Albert, Auckland, New Zealand
}

\begin{abstract}
There have been numerous concerns about the lack of productivity improvement in the New Zealand construction industry. The aim of this paper, therefore, is to determine the main drivers of productivity in the industry. The research used is a two-staged data envelopment analysis approach to achieve the aim. In terms of improvements to the productivity of construction in New Zealand, the study found that although there is a potential for gains through the greater use of research and development, apprentice training and degree education, as well as the consolidation of some building companies, there will be some limits to the gains that might be made. One main implication of the findings of the study, therefore, is that a renewed focus on education and skills training should be a priority of companies and policy makers in New Zealand.
\end{abstract}

Keywords: Construction, productivity, data envelopment analysis

Paper Type: Research article

\section{Introduction}

There has been undertaken in recent years a number of attempts to determine the main factors that drive changes in construction industry productivity and efficiency. In the past most studies of this sort have been focused on the United States construction industry, although in recent years additional research has been undertaken in number of other countries (see for instance: Chiu and Wang 2011; Li and Liu 2011). In the United Kingdom for instance, a range of performance indicators in the construction industry are collected by the British Government (United Kingdom Department of Business Enterprise and Regulatory Reform 2008). In undertaking this research one aspect of the construction industry that has been found is a perceived stagnation, or even decline, of productivity growth. In determining the causes of this phenomenon there has been a degree of controversy. One view that has been expressed is that the stagnation has been caused by the basic character of the industry. To a large degree the construction industry is a labour intensive one, which means (it has been argued) that the introduction of new equipment and technology can only increase production levels with a given amount of capital and labour; therefore making productivity improvements difficult (Allen,

\footnotetext{
Copyright: Construction Economics and Building 2015. (C) 2015 Will Chancellor, Malcolm Abbott and Chris Carson. This is an Open Access article distributed under the terms of the Creative Commons Attribution 4.0 Unported (CC BY 4.0) License (https://creativecommons.org/licenses/by/4.0/), allowing third parties to copy and redistribute the material in any medium or format and to remix, transform, and build upon the material for any purpose, even commercially, provided the original work is properly cited and states its license.
}

\footnotetext{
Citation: Chancellor, W., Abbott, M. and Carson, C., 2015. Factors promoting innovation and efficiency in the construction industry: a comparative study of Australia and New Zealand, Construction Economics and Building, 15(2), 63-80. DOI:

http://dx.doi.org/10.5130/AJCEB.v15i2.4386
}

Corresponding author: Malcolm Abbott; Email - mabbott@swin.edu.au

Publisher: University of Technology Sydney (UTS) ePress 
1985). Another explanation proposed is that inappropriate price indexes have been used in determining productivity measures and therefore the perceived stagnation is not as serious as it appears (Dacy, 1965; Stokes, 1981). A related view is that the official data on construction industry activity does not take into account improvements in the quality of the construction outputs produced and so therefore improvements have not been detected (Rosefielde and Mills, 1979). One final view is that that much of the stagnation in productivity can be attributed to a change in the output mix from high to low productivity building projects (Schriver and Bowlby, 1985). Whatever the cause of the perceived stagnation, it is likely that methodological issues are making it difficult to determine the degree to which productivity in the industry has changed, and what the causes of any changes are.

One measure that has been used to try and estimate the levels of productivity in the industry that attempts to overcome the basic methodological difficulty is an approach known as Data Envelopment Analysis (DEA). It is a method which has been utilised for a number of years and has generally been used as a means of benchmarking the performance of different companies. It has also been used to determine productivity changes over time (effectively benchmarking the companies or industry against itself in different years). In using DEA one approach has been to determine the relative efficiency scores of the companies or industry studied, and then to regress a range of explanatory variables against the DEA efficiency scores in order to identify, which of the variables have the most notable impact on the efficiency levels. This so called "two-staged" approach to productivity analysis has been used in a number of industry cases, but has only been used rarely in the construction industry (for examples see: Horta, Camanho and Moreirada, 2012 for Portugal and Edvardsen, 2005 for Norway).

In New Zealand the determination of construction industry productivity levels has raised a number of issues. In particular concerns have been expressed about the lack of productivity improvement in the construction industry in New Zealand (for reviews see Abbott and Carson, 2012 and Van Dai Tran, 2010). This lack of productivity growth has been related to the concerns for the decline in the affordability of housing in New Zealand (for investigations into the industry see New Zealand, Department of Building and Housing, Productivity Taskforce, 2009; New Zealand Productivity Commission, 2011). A two-staged DEA approach to determining the main drivers of changes in productivity in the industry in New Zealand would help to establish what the main drivers of productivity in the industry are. It would provide a way in which to avoid some of the methodological issues that have been encountered in studying the industry and help to identify some of the principle productivity change drivers.

In this paper, a two-stage, DEA approach is utilised to find the drivers of the New Zealand construction industry's productivity change. In undertaking this study Australian data is also used to help to further identify and explain the New Zealand drivers. The structure of the paper is as follows: The first section has a general background on DEA, along with a description of productivity change in the New Zealand construction industry. A section is then given on the data and methodology used. Results are then provided and conclusions are made in the last section.

\section{DEA and Past Studies}

In the New Zealand case it has been generally recognised in official statistical sources that the construction industry in that country has a productivity level which sits at much the same level that it did in the late 1970s (Statistics New Zealand, 2012, Industry productivity statistics). A number of possible reasons have been put forward that seek to explain this lack of growth in productivity since the 1970s including: low levels of workforce skills, a deficiency of competition in the construction market, too low economies of scale achieved in the industry, faulty management and innovation practice, regulatory impediments to change, and low and poor 
investment quality (New Zealand, Department of Building and Housing, Productivity Taskforce, 2009; Van Dai Tran, 2010; New Zealand Productivity Commission, 2011).

Over the years a number of researchers in New Zealand have made estimates of New Zealand's productivity change (reviews include: Abbott and Carson, 2012 and Van Dai Tran, 2010). These studies have tended to be part of larger multi-industry studies, which simply include construction as part of the broad approach. Studies of this sort include those by Orr (1989); Chapple (1994); Philpott (1991, 1993, 1995); Färe, Grosskopf and Margaritis (1996), Diewert and Lawrence (1999); Black, Guy and McLellan; Mason and Osborne (2007) and Janssen and McLoughlin (2008). In addition Davis (2007) undertook a study that concentrated just on construction productivity.

Regardless of the periods selected, the various studies show that although construction productivity increased to some degree up until the mid-1970s, since then the results have been mixed. This appears to be the case even though a range of technological changes have taken place. Since the 1970s the industry has seen the introduction of additional hand-held powered tools (nail drivers, sanders, saws and drills), improved lifting and moving machinery (cranes, loaders, earth movers, graders, forklifts), and the introduction of new materials and processes, along with the greater use of pre-fabricated materials.

Most of the past studies of the New Zealand construction industry have used an index approach to determining productivity. This may mean that the results have been distorted in the manner mentioned in the studies cited earlier (Allen 1985; Dacy 1965; Stokes 1981) for the construction industry in the United States. The use of DEA to overcome these methodological problems in the New Zealand case is less common (for New Zealand examples see: Färe, Grosskopf and Margaritis, 1996; Abbott and Carson, 2013). As DEA does not require price data, it is able to overcome some of the methodological issues associated with distorted price indexes. These distorted price indexes arise often because companies and government service providers often function in markets, where costs and prices are established under conditions that lack competition. This means that the normal measures of performance - such as profits or rates of return - can't be made use of to determine an organisation's (or industry's) performance (often these are instead an indication of an organisation's degree of market power). In these cases it is more appropriate to use productivity measures that do not rely on output and input prices. DEA is a technique that achieves this.

Charnes, Cooper, and Rhodes (1978) first pioneered the use of DEA and based their work on that by Farrell (1957) (see for example: Färe, Grosskopf and Knox Lovell, 1985; Knox Lovell and Schmidt, 1988 and Coelli et al., 2005). It is a technique of linear programming that involves the estimation of the productivity and efficiency of organisations (or industries) through the measuring of output to input ratio employed for a range of sampled organisations. These ratios in the sample are then compared to each other in order to arrive at an estimate of relative efficiency. Each of the organisations sampled then receives an efficiency score that is estimated as being the variance of their ratio from the most efficient in the sample. The advantage of DEA is that it can be used without needing output or input prices, which is useful if the actual prices are distorted by market conditions. Data envelopment analysis is advantageous over other methods such as Stochastic Frontier Analysis as it only requires input and output quantities. Stochastic frontier analysis requires data on total cost, output quantities and input prices (Coelli et al., 2005). Another advantage is that it is a non-parametric method, which means that making assumptions about the best practice frontier functional form is unnecessary (as is the case with Cobb-Douglas or translog cost function). DEA can also make use of multiple outputs and inputs and can be used to determine both scale and technical efficiency, without cost and price data.

As well as benchmarking organisations against each other, DEA can be used to estimate the 
change to productivity from one year to the next. The change in productivity is an indicator of how outputs relative to inputs change over time and generally reflects some changes in technical and allocative efficiency, technological improvements and improvements in the external environment. An organisation can improve its productivity over time either by moving towards a best practice frontier or move to higher levels when there is a frontier shift outwards, due to technological change. With this so-called Färe-Primont DEA approach, efficiency measures are derived for one year and then compared to the previous year. By doing so changes over time can be estimated for technical efficiency, technological progress, as well as total factor productivity. The method has been utilised in a number of different situations. It has, for instance, been used for determining productivity change for hospitals (Färe et al., 1994), for financial institutions (Berg, Forsund and Jansen, 1992; Worthington, 1999), for electricity and gas supply companies (Färe et al., 1990; Price and Weyman-Jones, 1996), and for airports (Abbott and Wu, 2002). A number of works explain the use of DEA in more detail; see for instance Coelli et al. (2005).

Regarding the construction industry it is possible, if sufficient data is available, to utilise DEA, either as a tool to benchmark and therefore show the relative efficiency of organisation units at any point in time; or to use DEA with the Färe-Primont approach to determine the change in productivity over time. Although DEA was originally devised as a benchmarking tool to show the relative performance organisations against each other, its common use in the construction industry has been to determine changes in industry level productivity over time.

The methods to analyse construction productivity have tended to make use of construction data at the national level, although three of the past studies have made use of state or provincial level data to increase the size of the data sample (see Xue et al., 2008; Li and Liu, 2011; Abbott and Carson, 2013). Industry level studies of this sort are of some interest to policy makers as they give information about the state of an industry's development, in general, but are of limited interest to those managing units within the industry.

The first example of the DEA approach being utilised to determine the change in construction industry productivity over time was undertaken by Färe, Grosskopf and Margaritis (1996) for the New Zealand construction industry. This work was undertaken as part of a broad economywide study of productivity change in New Zealand, where the work on the construction industry was just one of a number of industry level studies undertaken. The results of this study showed an average -0.4 per cent negative growth rate over the period, which was in line with other studies on the industry over the period (mostly using index approaches). The period 1974 to 1994 was a rather chequered one in New Zealand's economic history, containing as it did three recessions $(1974,1981,1991)$, along with a period of high inflation, and a serious loss of markets when Britain joined the European Economic Union. In the New Zealand case construction industry demand stagnated (due to substantial emigration to Australia) and investment in the industry fell. Productivity growth in the industry during this period, therefore, is usually regarded as being fairly slow, a combination of low capacity utilization and low investment in new technologies.

Since this work by Färe, Grosskopf and Margaritis was first undertaken other studies have been completed in a number of other countries that use DEA. These examples include the work by Chau and Wang (2005), Wang (1998); Wang and Chau (1997, 2001) on the construction industry in Hong Kong, Wang, Ye and Yuan (2010), and Xue et al. (2008) on the Chinese industry, and Li and Liu (2011) on the Australian industry. Unlike the New Zealand study in each of these cases the researchers found considerable increases in productivity over the studied periods. This was perhaps not unexpected as in each case (except the Australian one by $\mathrm{Li}$ and Liu) the studies were of developing countries in which the employment of additional capital drove productivity growth. In each case (including the Australian one) investment in capital accumulation and the introduction of technological developments in the construction industry were high. Rapid 
technological change was, therefore, found to be the experience in each case and these are shown in the results of each of these studies. In these cases what occurred was that over time the best practice frontier moved outwards due to the introduction of more advanced technologies.

When it comes to the selection of outputs and inputs in each of these studies, the inputs tended to be concentrated on combinations of labour (either the number of employees or work hours), as well as estimations of the value of capital. It has occurred in some cases that other inputs such as materials were also included (see for instance Wang 1998; Chau and Wang 2005). In the case of the value of capital inputs in some cases, a simple valuation of fixed assets was used (Xue, et al., 2008; Li and Lu, 2011) or alternatively an estimation of the cost of capital in terms of rents, interest and depreciation (Wang and Chau, 1997). Output tended to be determined by some valuation of the output of the industry, based on expenditure or the value added of construction from official statistical sources.

As well as showing changes in productivity what these studies also tried to do was identify some of the broad drivers of productivity change over time (such as improvements in technical and scale efficiency and technological change). They did not, however, identify a number of more specific drivers of productivity growth. It might be the case that this approach, using very highly aggregated data, and so cannot really be used to determine what the drivers of productivity change in the construction industry are. To do that DEA would be better used in conjunction with more data intensive firm or project level studies. This approach, however, is dependent to a substantial degree on the ability to obtain very detailed data at the project or firm level. It is probably not surprising therefore that there have been few studies of this sort undertaken.

Some examples of DEA benchmarking in the industry at the firm level include work by Edvardsen (2005) on Norwegian construction firms, Ingvaldsen (2005) on Norwegian building projects, McCabe, Tran and Ramani (2005) on Canadian construction firms, El-Mashaleh, Minchin and O'Brien (2007) on firms in Florida in the United States (Florida), and Chiu and Wang (2011) on firms in Taiwan.

Two of these papers on the construction industry go further by implementing a two staged approach to productivity change. The most important of these was the paper by Edvardsen (2005) that looked at the relative efficiency of a range of Norwegian construction companies. Edvardsen determined the efficiency levels for 342 construction companies in Norway in a single year using DEA by showing the relationship between the sales of the firms as the output and indicators of labour and capital as the inputs (labour man years and rental expenditure and depreciation). He then performed a second-stage regression that ran the relative efficiency levels of the firms as the regression's dependent variable, as well as a range of other variables as independent variables, in order to identify if the latter variables had any impact on the level of efficiency. The independent variables he used were such things as high average wages, long average hours of work, the number of apprentices employed, how diversified output was between different types of construction activity and the location of the main work of the companies, either in the main Norwegian city of Oslo or elsewhere. The study's results found that there was a correlation with having high skilled, well paid workers, who worked long hours on the one hand and levels of efficiency on the other. It also found that the more diversified companies had higher levels of efficiency. Companies located mainly in Oslo were not found to have any significant statistical relationship with higher levels of efficiency.

In the paper by Horta, Camanaho and Moreira da Costa (2012) on the Portuguese construction industry, a second stage regression was also undertaken using the variables of the size of GDP, the size of the firms, Rand D engagement and whether the firm was located in the capital and largest city of Portugal, Lisbon. The growth of GDP and the size of the firms were both positively correlated with levels of efficiency. 


\section{Methodology and Data}

In this paper the analysis undertaken made use of the Färe-Primont DEA method. This method was first proposed by O'Donnell (2011), and satisfied economic and mathematical assumptions such as inactivity, transitivity and boundedness. Use of the Färe-Primont DEA method is suitable when observing multiple outputs and inputs over time, as opposed to the Laspeyres, Paasche, Fisher and Malmquist indexes, which are suitable for comparing two observations at a time, otherwise known as binary indexes Equation (1) as in O'Donnell (2011) and O'Donnell (2012) was applied to estimate total factor productivity for the New Zealand and Australian construction industries. From a practical perspective, output and input data were arranged into a panel data format, and then loaded to software DPIN version 3.0 as discussed in O'Donnell (2011). This software uses a linear programming method to construct a frontier over data points as proposed by Farrell (1957), allowing for the specification of various commands. For the purposes of this analysis the following commands were selected: Färe-Primont index; variable returns to scale; unit means; and technical regress allowed. This configuration removes restrictions such as constant returns to scale and allows for technical change. This function uses the input and output distances functions proposed by Shephard (1965):

Färe-Primont: $\left\{\begin{array}{l}Q\left(\boldsymbol{q}_{t}\right) \propto D_{o}\left(\bar{x}_{y} \boldsymbol{q}_{t^{\prime}} \bar{z}\right) \\ \boldsymbol{X}\left(\boldsymbol{x}_{t}\right) \propto D_{i}\left(x_{c^{y}} \bar{q}_{\bar{z}} \bar{z}\right)\end{array}\right.$

Where:

$$
\begin{aligned}
& \mathrm{q}=\text { Output quantity } \\
& \bar{\sigma}_{\text {जा }}=\text { Sample mean of output quantity } \\
& \mathrm{x}=\text { Input quantity } \\
& \bar{x}_{\text {业 }}=\text { Sample mean of input quantity } \\
& z=\text { External variables } \\
& \bar{z} \bar{n}=\text { Sample mean of external variables } \\
& D_{0}=\text { Shephard output distance function } \\
& D_{i}=\text { Shephard input distance function }
\end{aligned}
$$

As outlined in Coelli et al. (2005), the Shephard output distance function works by giving the maximum output while holding the input fixed (Shephard, 1970). Conversely, the Shephard input distance function gives the minimum inputs while holding the outputs fixed (Shephard, 1970). These functions were used to control input or output oriented measures of DEA. The Shephard input and output functions were formally defined by Equations 6 and 7 .

Input distance function:

$\operatorname{Di}(x, q, z)=\sup \left\{p>0:\left(\frac{x}{p}, q\right) \in Y(z)\right\}$

Output distance function:

$$
D_{o}(x, q, z)=\inf \left\{\delta>0 ;\left(x, \frac{q}{\delta}\right) \in T(z)\right\}
$$

The use of both input and output orientation enabled an additional layer of analysis which was found to be generally overlooked in existing DEA research. Coelli et al., (2005) explain the 
conceptual difference, such that input orientation estimates the minimum amount of inputs required to produce the same outputs, and output orientation measures the maximum amount of output that can be produced with fixed inputs. Input orientation is the most appropriate orientation for the purposes of the construction industry since the inputs of capital and labour are the decision variables, as opposed to output variables such as floor space which is often decided externally.

The Färe-Primont DEA method was used to initially produce comparative productivity growth estimates for New Zealand and Australian construction from 1991 to 2010. These estimates used two outputs (engineering and non-residential expenditure and residential floor space), and two inputs (construction labour and construction capital). Monetary data was standardised using purchasing power parity (PPP) figures so that the exchange rate effect could be removed from productivity estimation, allowing for a more accurate comparison between two different countries.1 Productivity growth estimates were then produced for the individual states of Australia compared to New Zealand using the same method.

Using Färe-Primont DEA, productivity growth estimates for New Zealand were decomposed into levels of technical and scale efficiency. This decomposition enabled the derivation of input and output scale and technical efficiencies. Technical efficiency is defined as an ability to obtain maximum output from given inputs. Scale efficiency is defined as an ability to improve efficiency by changing the scale of operations (Balk, 2001). Given the relationship between productivity growth and efficiency levels, improvements in efficiency tend to lead to improvements in productivity growth (Coelli et al., 2005).

Using DEA, New Zealand and Australian productivity estimates were decomposed into various measures of efficiency, including technical and scale efficiency. These efficiency measures could be decomposed from either input or output orientation. For the purposes of this research, input orientation is more relevant, as construction firms tend to have more control over their inputs of labour and capital than their outputs of floor space. As in Coelli et al., (2005) input and output orientated technical and scale efficiency are represented in Equations 4, 5, 6 and 7.

Input-oriented technical efficiency (movements toward or away from the frontier):

$I T E_{\text {it }}=\frac{Q_{\text {it } j} X_{\text {it }}}{Q_{\text {it } f} \bar{X}_{\text {it }}}=\frac{\bar{X}_{\text {it }}}{X_{\text {it }}}=D_{I}\left(x_{i t} q_{i t} t\right)^{-1} \leq 1$

Output-oriented technical efficiency (movements toward or away from the frontier):

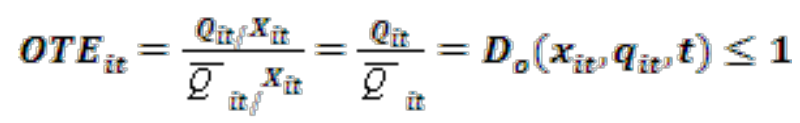

\footnotetext{
1 The sources of data for inputs and outputs are: Labour: Australian Bureau of Statistics (2014). Labour Force, Australia, cat no. 6291.0., Canberra: Australian Bureau of Statistics. Statistics New Zealand (2014c). Labour Market Statistics. Wellington: Statistics New Zealand. Capital: Australian Bureau of Statistics (2014). Australian National Accounts: State Accounts, cat no. 5220.0, Canberra: Australian Bureau of Statistics. Statistics New Zealand (2014b). National Accounts. Wellington: Statistics New Zealand. Output: Australian Bureau of Statistics (2014). Australian National Accounts: State Accounts, cat no. 5220.0, Canberra: Australian Bureau of Statistics. Statistics New Zealand (2014b). National Accounts. Wellington: Statistics New Zealand. Australian Bureau of Statistics (2014). Building Activity, Australia. cat no. 8752.0, Canberra: Australian Bureau of Statistics. Statistics New Zealand (2014e). Building Consents Issued. Wellington: Statistics New Zealand. Prices: Australian Bureau of Statistics (2014). Consumer Price Index, Australia. cat no. 6401.0, Canberra: Australian Bureau of Statistics. Statistics New Zealand (2014d). Consumers Price Index. Wellington: Statistics New Zealand.
} 
Input-oriented scale efficiency change (movements around the frontier surface to capture economies of scale):

$I S E_{i t}=\frac{Q_{i t} / \bar{X}_{i t}}{\oint_{\text {it }} \tilde{X}_{\text {it }}} \leq \mathbf{1}$

Output-oriented scale efficiency change (movements around the frontier surface to capture economies of scale):

$O S E_{i t}=\frac{\bar{Q}_{i t} X_{i t}}{\oint_{\text {it }} \tilde{X}_{\text {it }}} \leq 1$

Regression analysis was then used to compare productivity growth estimates as the dependent variables, to various independent variables thought to influence construction industry productivity and efficiency. The regression initially tested whether an independent variable had a significant correlation with a dependent productivity growth estimate. The direction of influence (either positive or negative) and the amount of influence was also then established. Figure 1 illustrates the regression model used in AMOS (IBM, 2013). The dependent variable productivity estimates were derived initially using Färe-Primont DEA. The independent variables were co-varied and rotated throughout the analysis. For example, the independent variable was set to equal construction education in the corresponding productivity region. This independent variable could then be changed to population for the corresponding region, and so on. The independent variables are listed in Table 1.

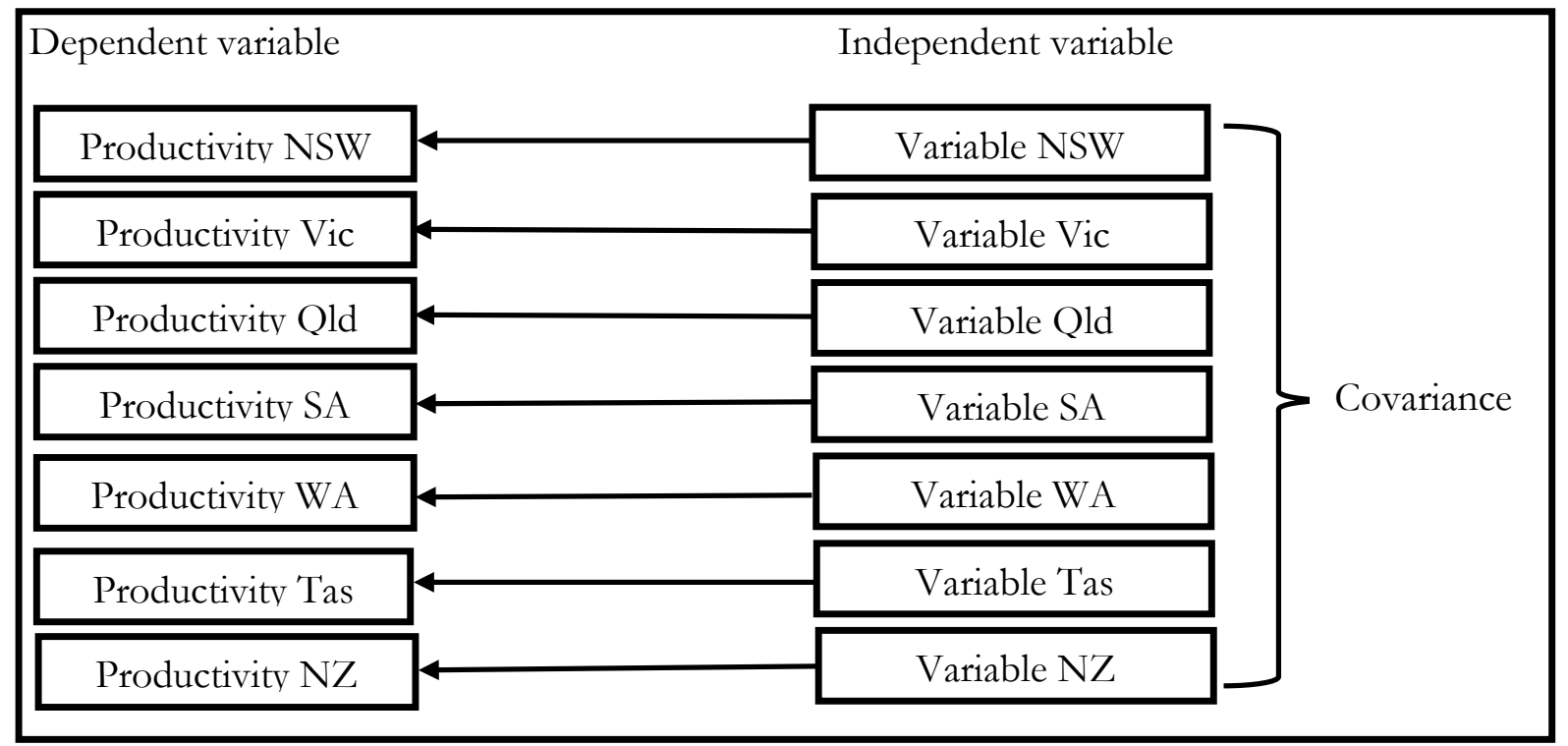

Figure 1: Regression model for Australian and New Zealand construction

Population growth and its relationship to the demand and supply of construction services was expected to have some impact on productivity growth, particularly with comparison between New Zealand and Australia - countries with differing levels of population growth. Australia has 
experienced long and consistent population growth whereas population growth in New Zealand has experienced more moderate growth and periods of population decline.

Table 1: Independent variable descriptions and sources

\begin{tabular}{|c|c|c|c|}
\hline $\begin{array}{l}\text { Independent } \\
\text { variable }\end{array}$ & Data description & NZ Source & AU Source \\
\hline Population growth & $\begin{array}{l}\text { Count of population } \\
\text { over time }\end{array}$ & $\begin{array}{l}\text { Statistics New } \\
\text { Zealand 2014a. } \\
\text { National Population } \\
\text { Estimates }\end{array}$ & $\begin{array}{l}\text { Australian Bureau of } \\
\text { Statistics (Catalogue } \\
\text { number 3101.0) }\end{array}$ \\
\hline Education & $\begin{array}{l}\text { Number of degrees } \\
\text { over time in construction }\end{array}$ & $\begin{array}{l}\text { Statistics New } \\
\text { Zealand } 2014 \mathrm{f} . \\
\text { Census }\end{array}$ & $\begin{array}{l}\text { Australian Bureau of } \\
\text { Statistics. Census. }\end{array}$ \\
\hline $\begin{array}{l}\text { Research and } \\
\text { Development }\end{array}$ & $\begin{array}{l}\text { Percentage investment in } \\
\text { construction research and } \\
\text { development }\end{array}$ & $\begin{array}{l}\text { Statistics New } \\
\text { Zealand 2014b, } \\
\text { National Accounts }\end{array}$ & $\begin{array}{l}\text { Australian Bureau of } \\
\text { Statistics (Catalogue } \\
\text { number 8104.0). }\end{array}$ \\
\hline Apprentices & $\begin{array}{l}\text { Count of construction } \\
\text { apprentices over time }\end{array}$ & $\begin{array}{l}\text { Statistics New } \\
\text { Zealand. } \\
\text { Information } \\
\text { custom data request }\end{array}$ & $\begin{array}{l}\text { National Centre for } \\
\text { Vocational Education } \\
\text { Research }\end{array}$ \\
\hline
\end{tabular}

Education has been considered by other researchers (Banks 2002; McGrath-Champ, Rittau and Rosewarne, 2010) to be a driver of productivity growth, resulting from increased technical efficiency through improved skill, management, reduced rework and process improvement. It was therefore an important variable to measure whether change in education levels within the construction industry had influenced productivity growth.

Research and development has been considered a driver of productivity by other researchers including Färe, Grosskopf and Margaritis (1996), Davis (2007), and Budiawan and Sidwell (2004). Innovation through research and development has a number of productivity advantages including improvement technical efficiency, improved quality of construction, reduction in cost, improved reliability and other intangible benefits (Budianwan and Sidwell, 2004).

Similarly to education, the number of construction apprentices provides an indication of skill within the construction industry. Productivity improvements through skill result from technical efficiency gains, through improved work practices, reduced rework and process improvement. Apprentices could also be considered to have some negative effect on productivity and efficiency in the short term, due to worksite training burden through the distraction of experienced workers away from productive tasks. This training burden is expected to be relatively low and shared between the offsite apprenticeship training institutes.

\section{Results}

Productivity growth was estimated for New Zealand and Australia using the Färe-Primont DEA method, allowing for a comparative analysis. Initially, productivity growth was estimated at national level for both New Zealand and Australia (Figure 2). Secondary productivity analysis was then completed to compare construction productivity in New Zealand to the levels of the individual states of Australia (Figure 3).

National level results for Australia in Figure 2 indicated stagnant construction productivity growth. Australian construction productivity experienced a significant downturn from 2000 to 2002. A possible explanation for this downturn is the introduction of the Goods and Services Taxation system in Australia, which influenced construction activity timing (Australian Bureau of 
Statistics, 2007). From 2002 onwards, productivity in Australian construction achieved minimal growth.

Using state level data, Australian construction productivity growth estimates were produced in Figure 3. These estimates reveal that Australian construction productivity growth has been propped up by growth in the states of Queensland, Western Australia and Victoria. Construction productivity growth in these states has accelerated since 2000, and coincidently these states have also undertaken the highest amounts of heavy civil engineering construction mining infrastructure in the case of Queensland and Western Australia and other large projects such as the East Link freeway and a desalination plant in Victoria (Australian Bureau of Statistics, 2014; National Infrastructure Construction Schedule, 2013).

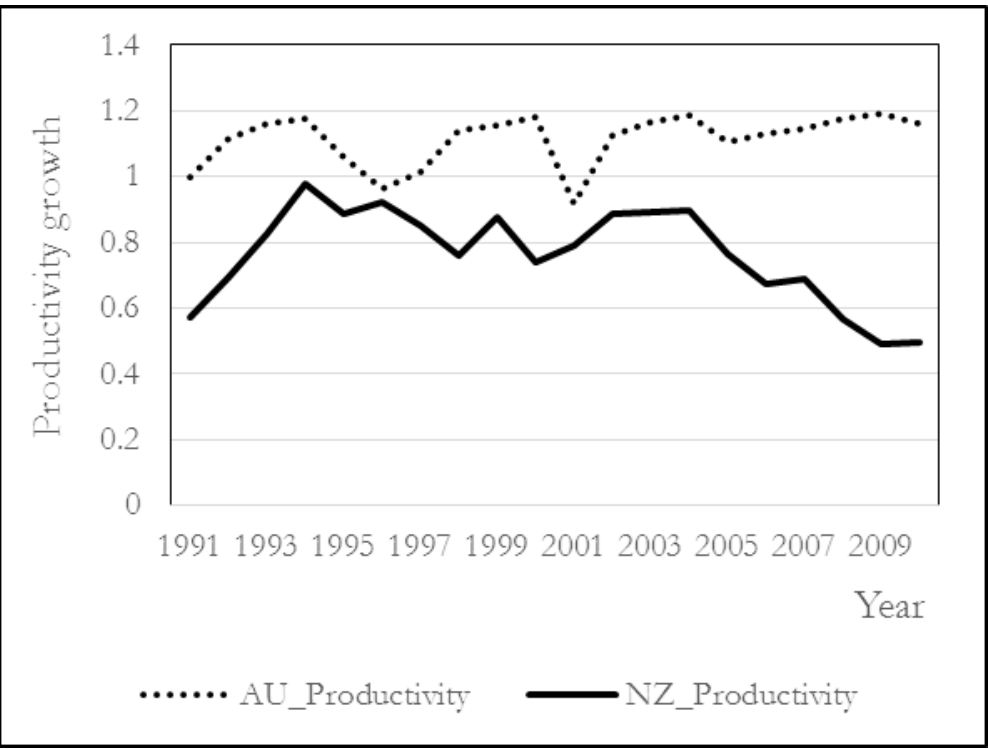

Figure 2: Productivity index - Australia and New Zealand

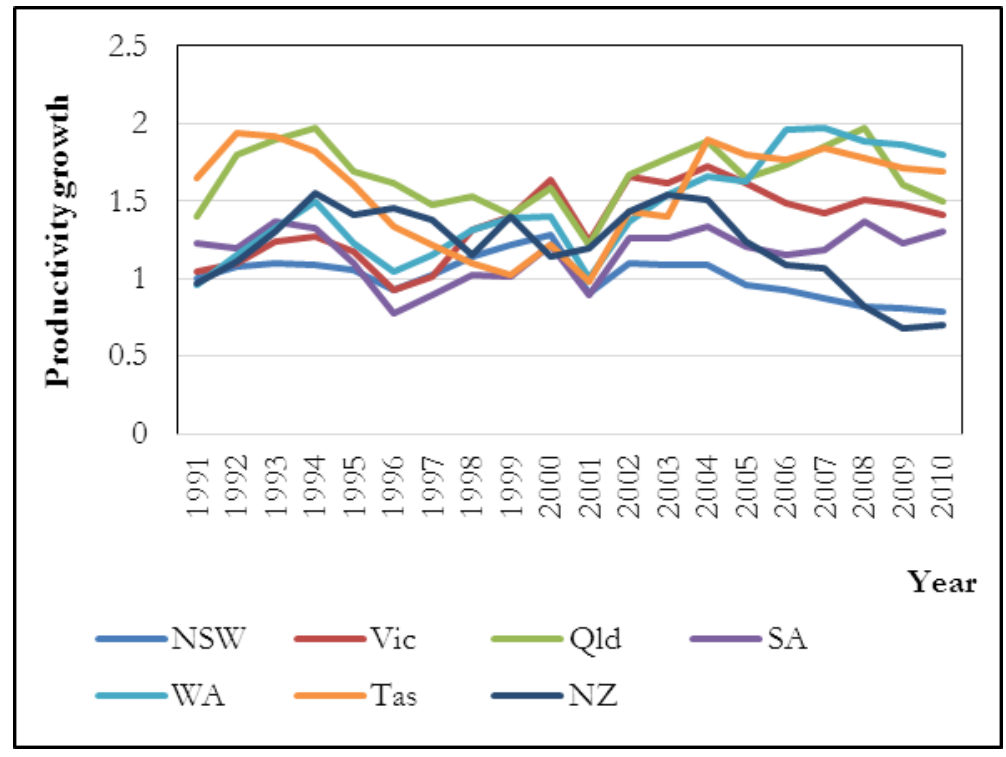

Figure 3: Productivity index - Australian states and New Zealand

Productivity growth in South Australia and New South Wales were identified as points of weakness in the Australian construction industry. Estimates shown in in Figure 3 indicate that construction productivity in these two states had grown well below the Australian average. 
New Zealand construction productivity grew strongly from 1991 to 1994 and then continued along a stagnant trajectory up until 2004 (Figure 2 and 3). The data used in this analysis revealed strong growth in both residential and non-residential outputs, along with limited input growth, during the early 1990s. From 2004 onwards, construction productivity in New Zealand experienced a period of a decline in growth. Analysis of the data used revealed a decline in residential construction outputs, with inputs remaining relatively constant.

To partially explain the stagnant and declining productivity growth in New Zealand construction, productivity growth estimates where decomposed into output and input technical and scale efficiency (Figure 4).

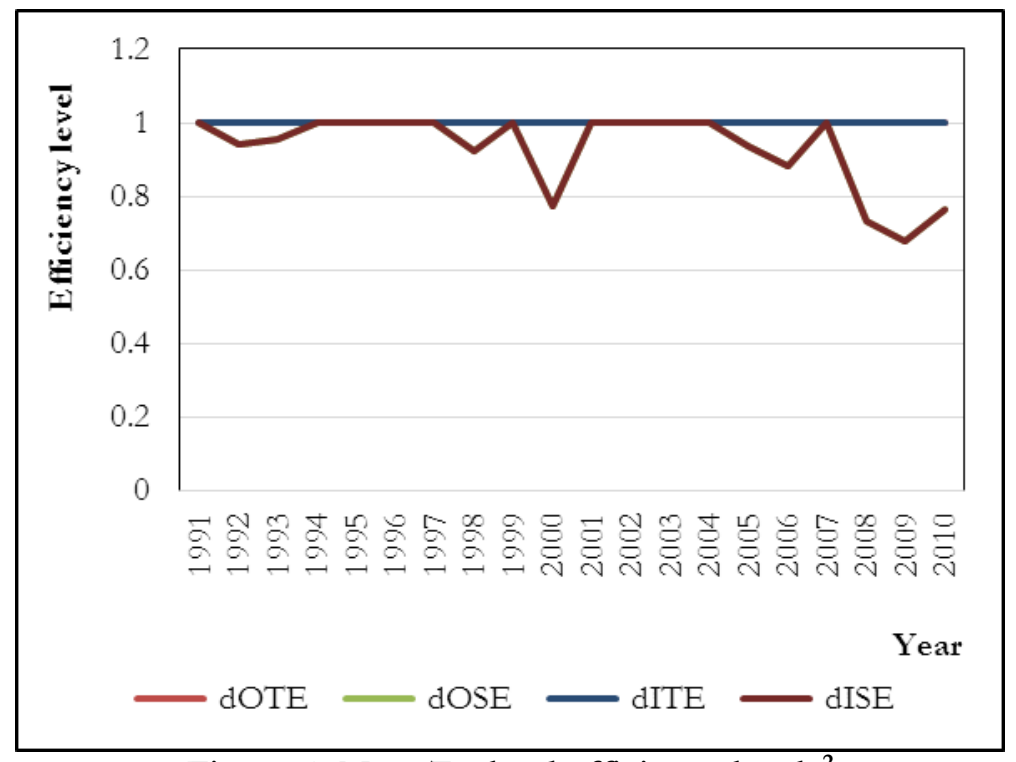

Figure 4: New Zealand efficiency levels ${ }^{2}$

A time series of input and output, scale and technical efficiencies were derived using FärePrimont DEA, which resulted in values between zero and one for each year from 1991 to 2010. A value of one indicated that the observation was on the DEA frontier, and thus had achieved full technical efficiency for the respective period. Conversely a value of less than one was an indication of inefficiency.

Analysis of efficiency results for New Zealand construction in Figure 4 indicated an industry operating at full input and output technical efficiency (dITE and dOTE respectively). The most notable feature from Figure 4 were the periods of scale input and output inefficiency (dISE and dOSE respectively). These results suggest that the New Zealand construction industry has reached a theoretical point of maximum technical efficiency, however was restricted by scale inefficiency. This point of maximum technical efficiency is based on the outputs and inputs used, and is a theoretical calculation. In practice there are other unmeasurable variables not considered in this calculation, meaning that while these results indicate New Zealand technical efficiency is strong, in reality it is unlikely to have reached a point of perfect technical efficiency. The scale inefficiency identified in Figure 4 partially explained the declining construction productivity growth in New Zealand. Fletcher Building (2011) also identified scale problems with New Zealand construction, noting that the industry is dominated by small firms, categorising it as a 'cottage industry'. Fletcher Building (2011) compared the New Zealand and Australian construction industries, finding a considerably lower proportion of house builders and multi-unit home designers in New Zealand.

\footnotetext{
2 dOTE(Output-oriented Technical Efficiency), dOSE (Output-oriented Scale Efficiency), dITE(Input-oriented Scale Efficiency), dISE(Input-oriented Scale Efficiency)
} 
To explore the possible factors influencing or driving construction productivity in New Zealand and Australian, a second-stage regression was applied. This regression used productivity estimates as the dependent variables, and a range of other factors as independent variables, in order to identify if the latter variables had any correlation to productivity. The independent variables used were population growth, education, research and development and apprentices (Table 1). This method of analysis identified whether an independent variable had a significant or insignificant relationship with the respective productivity estimates. If so, it also determined the direction and size of the relationship.

It was expected that the decline in New Zealand construction productivity from 2004 to 2010 had distorted regression analysis results. To test this, an additional dependent variable (NZ_adj) was included in the regression analysis. The adjusted estimates removed the productivity decline from 2004 to 2010It was highly likely that the unadjusted figures had obscured the regression results, since productivity growth had declined steeply in New Zealand construction from 2004 to 2010 while the various independent variables had experienced a corresponding increase.

Regression results presented in Table 2 show values where significant relationships between construction productivity and the various independent variables were identified. Blank values represent an insignificant relationship. The actual table value refers to a regression weights for a significant independent variable, and indicates the amount by which a change in an independent variable influenced change in productivity growth. For example, education was found to be significant and positive in New Zealand with a regression weighting of 0.124 . This means that if New Zealand construction education was to increase by 1, New Zealand construction productivity would be expected to increase by 0.124 .

Table 2: Second-stage regression results

\begin{tabular}{|lcccccccc|} 
& NSW & Vic & Q1d & SA & WA & Tas & NZ & NZ_adj \\
\hline Population growth & -0.198 & 0.436 & & & 1.355 & & -0.478 & 0.451 \\
\hline Education and & -0.022 & 0.037 & & & 0.026 & & -0.164 & 0.124 \\
\hline $\begin{array}{l}\text { Research } \\
\text { Development }\end{array}$ & -0.265 & 0.178 & 0.118 & 0.060 & 0.397 & 0.086 & & 1.324 \\
\hline \begin{tabular}{l} 
Apprentices \\
\hline
\end{tabular} & & 0.101 & & 0.263 & 0.311 & 2.940 & -0.423 & 0.302 \\
\hline
\end{tabular}

\section{Australia}

During the regression analysis several independent variables where found to be significantly correlated to Australian construction productivity growth. Population growth was found to have a positive effect on construction productivity in Victoria and Western Australia. Western Australia has achieved the strongest population growth of all Australian states in recent years, with strong migration growth also noted in Victoria (Australian Bureau of Statistics, 2013). Population growth in these areas was likely to have driven demand for residential construction, influencing construction output and productivity growth. In addition, heightened mining activity in Western Australia was expected to have attracted population growth to the region and generated demand for residential construction. Average annual population growth in Australia for the year ending 2013 was 1.7 per cent (Australian Bureau of Statistics, 2013).

Education was found to be positively correlated with construction productivity in Victoria and Western Australia. These results align with the expectation that the engineering construction component of the construction industry tends to be the most highly educated. In particular, a majority of construction demand in Western Australia has been mining construction and civil construction, attracting a highly skilled and educated construction workforce. Similarly, there 
have been high levels of engineering construction in Victoria in recent years, including the construction of the desalination plant and other infrastructure projects including major freeways in Melbourne (National Infrastructure Construction Schedule, 2013).

Construction research and development was found to be positively correlated to Australian construction productivity in all states except New South Wales. Expenditure on research and development leads to innovation and new technologies as has been considered by other researchers as a driver of productivity growth (Färe, Grosskopf and Margaritis, 1996; Davis, 2007). Innovation through research and development improves technical efficiency, quality of construction, reduction in cost, and improved reliability (Budianwan and Sidwell, 2004). These results suggest that Australian construction productivity has benefited from innovation through research and development

Apprenticeships and training has been considered by other researchers as a driver of productivity growth (Banks, 2002; McGrath-Champ, Rittau and Rosewarne, 2010). The Australian findings provide sufficient evidence to suggest that apprentices are beneficial to construction productivity growth in general. Apprentices bring new skills, motivation and innovation into the workplace. Apprentices were found to be positively correlated to construction productivity growth in Victoria, South Australia, Western Australia and Tasmania. It is expected that the negative results in New Zealand were due to a scale inefficiency problem. While apprentices are beneficial to a construction industry, they do absorb resources through training and supervision requirements.

\section{New Zealand 1991 - 2010}

Regression results using New Zealand construction productivity from 1991 to 2010 revealed a number of significant and negative independent variables for New Zealand construction (Table 2). Population growth, education and apprentices all appeared to have a negative relationship with New Zealand productivity growth. Examination of the independent variable data revealed that during the period from 2004 to 2010 when New Zealand construction productivity growth had sharply declined, the independent variables had generally increased. These negative regression relationships had been caused by the sharp decrease in New Zealand construction productivity growth, and not by the independent variables. To obtain more meaningful results, New Zealand construction productivity growth was adjusted to exclude the sharp decline from 2004 to 2010.

\section{New Zealand 1991 - 2004}

New Zealand construction productivity growth estimates were adjusted to exclude the sharp decline from 2004 to 2010 (NZ_adj in Table 2). This adjusted dependent variable was then regressed against the New Zealand independent variables in Table 1. Population growth in New Zealand was found to have a positive correlation to growth of productivity (Table 2). Increased population was expected to lead to general demand growth and investment in construction projects such as houses, schools, hospitals and roads. This growth in construction demand drives outputs and productivity growth.

Education was also found to have a positive correlation to New Zealand construction productivity growth (Table 2). These findings were consistent with Davis (2007) who noted that labour quality is likely to influence productivity growth as the industry is a labour intensive one. Sweetman (2002) also suggested that education produces human capital which is crucial to productivity growth.

Research and development represented the innovation component of the New Zealand construction industry. Table 2 shows that there is a positive correlation between research and 
development and the growth of productivity (Table 2). Davis (2007) also investigated innovation and its relationship to New Zealand construction productivity, finding that in New Zealand construction is one of the least innovative industries. Davis (2007) also notes the importance of innovation to construction productivity growth.

Apprenticeships were found to be significantly correlated to New Zealand construction productivity (Table 2). These results align with commentary by Davis (2007) who discussed that the introduction of new skills and formal qualifications in New Zealand construction is important to productivity growth.

\section{Conclusion}

From the study it is possible to make a number of conclusions. First of all there are problems that arise from the cyclical nature of the construction industry as demonstrated by fluctuating productivity results for both New Zealand and Australia. Large changes in business activity can affect productivity measures by changing the short run ratio of outputs to inputs. This affect is perhaps more acute in the construction industry than in most other industries, and more acute in New Zealand than in Australia. Care, therefore, needs to be made in constructing productivity change measures over time that are not too dominated by these cyclical movements. In the New Zealand case output in the industry has fallen from around 2004, which affects productivity estimates.

Overall the productivity of the construction industry is lower in New Zealand than Australia, but this can be at least partially explained by the greater economies of scale in Australia and the larger weight given to engineering construction in that country compared to commercial and residential construction. It is noteworthy that the Australian industry has experienced some periods of relative productivity stagnation, just as the New Zealand industry has. In the Australian case productivity growth appears to be propped up by growth in engineering activity. It is also noteworthy that the DEA estimates indicate a scale efficiency problem in the New Zealand market which reinforces the findings of previous work undertaken (Fletcher Building, 2011).

In the Australian case a number of factors were found to be important in driving productivity improvements. These include such things as population growth, education of people in the industry to degree level, the amount of research and development undertaken and the number of apprentices. Similar findings were found in the case on New Zealand, at least over the period 1991 to 2004, which appears consistent with some of the previous work done on the New Zealand construction industry (Davis, 2007).

Regarding improvements to the productivity of the construction industry in New Zealand, it appears that although there is potential for gains through the greater use of research and development, apprentice training and degree education, as well as the consolidation of some building companies as indicated by the scale inefficiency results, there will be some limits to the gains that might be made. The New Zealand industry faces problems of scale, a concentration on residential construction, as compared to engineering projects, and fairly substantial cyclical fluctuations that all make it difficult to push productivity levels higher.

\section{References}

Abbott, M. and Carson, C., 2012. A review of productivity analysis of the New Zealand construction industry. Australasian Journal of Construction and Building Economics, 12(3), pp.1-15. doi: http://dx.doi.org/10.5130/ajceb.v12i3.2584

Abbott, M. and Carson, C., 2013. A comparative approach to determining the growth of productivity of the New Zealand construction industry. Australasian Journal of Construction and Building Economics, 13(4), pp.65-77. doi: http://dx.doi.org/10.5130/ajceb.v13i4.3483 
Abbott, M, and Wu, S., 2002. Total factor productivity and efficiency of Australian airports. Australian Economic Review, 35(3), pp.244-60. doi: http://dx.doi.org/10.1111/1467-8462.00241

Allen, S.G., 1985. Why construction industry productivity is declining. Review of Economic Statistics, 117(4), 661-665. doi: http://dx.doi.org/10.2307/1924811

Australian Bureau of Statistics, 2007. Experimental Estimates of Industry Multifactor Productivity, cat. no. 5260.0.55.002. Available at: http://www.abs.gov.au/ausstats/Australian Bureau of Statistics@.nsf/mf/5260.0.55.002 [Accessed 23 Dec 2011].

Australian Bureau of Statistics, 2013. Australian Demographic Statistics, Cat. No. 3101.0, Dec 2013

Australian Bureau of Statistics, 2014. Engineering Construction Activity. Australia, Mar 2014, cat no. 8762.0. Canberra: Australian Bureau of Statistics.

Australian Bureau of Statistics, 2014. Labour Force, Australia, cat no. 6291.0., Canberra: Australian Bureau of Statistics.

Australian Bureau of Statistics, 2014. Australian National Accounts: State Accounts, cat no. 5220.0, Canberra: Australian Bureau of Statistics.

Australian Bureau of Statistics, 2014. Consumer Price Index, Australia. cat no. 6401.0, Canberra: Australian Bureau of Statistics.

Australian Bureau of Statistics, 2014. Building Activity, Australia. cat no. 8752.0, Canberra: Australian Bureau of Statistics.

Australian Bureau of Statistics, 2014. Census of Population and Housing. cat no. 2001.0, Canberra: Australian Bureau of Statistics.

Australian Bureau of Statistics, 2014. Research and Experimental Development, Businesses, Australia. cat. no. 8104.0, Canberra: Australian Bureau of Statistics.

Balk, B.M., 2001. Scale efficiency and productivity change. Journal of Productivity Analysis, 15, pp.159-83. doi: http://dx.doi.org/10.1023/A:1011117324278

Banks, G., 2002. The Drivers of Australia's Productivity Surge. Melbourne: Productivity Commission. Available at: http://www.pc.gov.au/speeches/cs20020307. [Accessed 10 January 2013].

Berg, S.A., Forsund, F.R. and Jansen, E.S., 1992. Malmquist indices of productivity growth during the deregulation of Norwegian banking, 1980-89. Scandinavian Journal of Economics, 94, pp.211-28. doi: http://dx.doi.org/10.2307/3440261

Black, M., Guy, M. and McLellan, N., 2003. Productivity in New Zealand 1988 to 2002. Treasury Working Paper 03/06. Wellington: The Treasury.

Budiawan, D. and Sidwell, A.C., 2004. Drivers of Construction Innovation. Construction Industry Institute, Australia.

Chapple, S., 1994. 'Searching for the Heffalump?' An exploration into sectoral productivity and growth in New Zealand. New Zealand Institute of Economic Research Working Paper 99/10, Wellington.

Charnes, A., Cooper, W.W. and Rhodes, E., 1978. Measuring the efficiency of decision making units. European Journal of Operational Research, 2(6), pp.429-44. doi: http://dx.doi.org/10.1016/0377-2217(78)90138-8

Chau, K.W. and Wang, Y.S., 2005. An analysis of productivity growth in the construction industry: a non-parametric approach. In Khosrowshahi, F. (ed.) 21 ${ }^{\text {st }}$ Annual ARCOM conference, 7-9 September 2005, SOAS, University of London. Association of Researchers in Construction Management, 1, pp.159-69.

Chiu, C.Y. and Wang, M.W., 2011. An integrated DEA based model to measuring financial performance of construction companies. WSEAS Transactions on Business Economics, 1(8), pp.1-15.

Coelli, T.J, Prasada Rao, D.S., O’Donnell, C.J. and Battese, G.E. 2005. An Introduction to Efficiency and Productivity Analysis. Springer Science Business Media, LLC second edition

Dacy, D.C., 1965. 'Productivity and price trends in construction since 1947'. Review of Economics and Statistics, 47(4), pp.406-11. doi: http://dx.doi.org/10.2307/1927769

Davis, N., 2007. Construction Sector Productivity Scoping Report. Wellington: MartinJenkins.

Diewert, E. and Lawrence, D., 1999. Measuring New Zealand's Productivity. Treasury Working Paper 99/5. Wellington: Treasury.

Edvardsen, D.F., 2005. Economic efficiency of contractors. In: Kaehkoenen, K. and Porkka, J. (eds.) Global Perspectives on Management and Economics in the AEC sector, Volume II. 11th Joint CIB International Symposium Combining Forces - Advancing Facilities Management and Construction through Innovation. 13 Jun 2005 - 16 Jun 2005, Helsinki.

El-Mashaleh, M.S., Minchin, R.E. and O’Brien W.J., 2007. Management of construction firm performance using benchmarking. Journal of Management in Engineering, 23, pp.10-17. doi: http://dx.doi.org/10.1061/(ASCE)0742597X(2007)23:1(10)

Färe, R., Grosskopf, S. and Knox Lovell, C.A., 1985. The Measurement of Efficiency of Production. Boston: KluwerNijhoff. doi: http://dx.doi.org/10.1007/978-94-015-7721-2

Färe, R., Grosskopf, S., Lingren, B. and Roos, P., 1994. Productivity developments in Swedish hospitals: a Malmquist output index approach. In: Charnes, A., Cooper, W.W., Lewin, A.Y. and Seiford, L.M. (eds.) Data Envelopment Analysis: Theory, Methodology and Applications. Boston: Kluwer Academic Publishers. doi: http://dx.doi.org/10.1007/978-94-011-0637-5 13 
Färe, R., Grosskopf, S. and Margaritis, D., 1996. Productivity growth. In: B. Silverstone, A. Bollard and R. Lattimore (eds.) A Study of Economic Reform: the Case of New Zealand. New York: Elsevier Science.

Färe, R., Grosskopf, S., Yaisawarng, S., Li, S. and Wang, Z., 1990. Productivity growth in Illinois electricity utilities. Resources and Energy, 12, pp.383-98. doi: http://dx.doi.org/10.1016/0165-0572(90)90030-M

Farrell, M., 1957. The measurement of productive efficiency. Journal of the Royal Statistical Society, Series A(CXX), pp.253-81. doi: http://dx.doi.org/10.2307/2343100

Fletcher Building, 2011. Submission to the New Zealand Productivity Commission Inquiry into Housing Affordability. Available at: $\quad$ http://www.productivity.govt.nz/sites/default/files/Sub $\% 20021 \% 20$ -

\%20Fletcher $\% 20$ Building $\% 20$ Submission.pdf 9 [Accessed 12 September 2014].

Horta, I.M., Camanho, A.S. and Moreira da Costa, J., 2012. Performance assessment of construction companies: a study of factors promoting financial soundness and innovation in the industry. International Journal of Production Economics, 137(1), pp.84-93. doi: http://dx.doi.org/10.1016/j.ijpe.2012.01.015

IBM, 2013. SPSS Amos. Available at: http://www-142.ibm.com/software/products/au/en/spss-amos/. [Accessed 03 January 2013].

Invaldsen, T., 2005. Scientific benchmarking of building projects - model and preliminary result. In: Kazi, A.S. (ed.) Systematic Innovation in the Management of Construction Projects and Processes, Volume III.

Janssen, J. and McLoughlin, S., 2008. New Zealand's Productivity Performance. New Zealand Treasury Productivity Paper 08/02, Wellington: The Treasury.

Knox Lovell, C.A., and Schmidt, P., 1988. A comparison of alternative approaches to the measurement of productive efficiency. In: A. Dogramaci and R. Färe (eds.) Applications of Modern Production Theory: Efficiency and Productivity. Boston: Kluwer. doi: http://dx.doi.org/10.1007/978-94-009-3253-1 1

Li, Y. and Liu, C., 2011. Construction capital productivity measurement using data envelopment analysis. International Journal of Construction Management. 11(1), pp.49-61. doi: http://dx.doi.org/10.1080/15623599.2011.10773161

McCabe, B., Tran, V and Ramani, J., 2005. Construction prequalification using data envelopment analysis. Canadian Journal of Civil Engineering, 32, pp.183-93. doi: http://dx.doi.org/10.1139/104-073

McGrath-Champ, S., Rittau, Y. and Rosewarne, S., 2010. Education, skill and unions in the Australian construction industry. Labour and Industry, 21(1), pp. 438-462. doi: http://dx.doi.org/10.1080/10301763.2010.10669413

Mason, G. and Osborne, M., 2007. Productivity, Capital-Intensity and Labour Quality at Sector Level in New Zealand and the UK. New Zealand Treasury Working Paper 07/01, Wellington.

National Infrastructure Construction Schedule, 2013. Projects. Available at: https://www.nics.gov.au/Project [Accessed 01 July 2013].

New Zealand Department of Building and Housing, Productivity Taskforce, 2009. Report of the Building and Construction Sector Productivity Taskforce: a Modern Efficient and Productive New Zealand Built Infrastructure Industry. Wellington: NZ: Dept. of Building and Housing.

New Zealand Productivity Commission, 2011. Housing Affordability Inquiry: Draft Report. Wellington: Productivity Commission.

O’Donnell, C., 2011. A Program for Decomposing Productivity Index Numbers. Centre for Efficiency and Productivity Analysis, The University of Queensland, Brisbane.

O’Donnell, C., 2012. Applied Productivity and Efficiency Course Notes, Centre for Efficiency and Productivity Analysis. School of Economics, The University of Queensland, Brisbane.

Orr, A., 1989. Productivity Trends in New Zealand: a Sectoral and Cyclical Analysis 1961-1987. Wellington: NZIER.

Philpott, B., 1991. Economic growth in New Zealand models and experience. In: Long Run Perspectives on the New Zealand economy. Proceedings of the Sesqicentennial Conference of the New Zealand. Association of Economists, New Zealand Association of Economists, Wellington.

Philpott, B., 1993. Data for sectoral productivity analysis and some preliminary results for 1978-93. RPEP Paper 256.

Philpott, B., 1995. New Zealand's Aggregate and Sectoral Productivity Growth 1960-1995. Research Project on Economic Planning Paper 274, Victoria University of Wellington, October, Wellington.

Price, C.W. and Weyman-Jones, T., 1996. Malmquist indices or productivity in the UK gas industry before and after privatization. Applied Economics, 28, pp.29-39. doi: http://dx.doi.org/10.1080/00036849600000004

Rosenfielde, S. and Mills, D.Q., 1979. Is construction technologically stagnant? In J.E. Lange and D.Q. Mills (eds.) The Construction Industry. Lexington MA: D.C. Heath and Company.

Schriver, W.R. and Bowlby, R.L., 1985. Changes in productivity and composition of output in building construction, 1972-1982. Review of Economics and Statistics, 67(2), pp.318-322. doi: http://dx.doi.org/10.2307/1924732

Shephard, R.W., 1965. Cost and Production Functions. Princeton: Princeton University Press.

Statistics New Zealand, 2012. Industry Productivity Statistics, 1978-2009. Wellington: Statistics New Zealand.

Statistics New Zealand, 2014a. National Population Estimates: Wellington: Statistics New Zealand.

Statistics New Zealand, 2014b. National Accounts. Wellington: Statistics New Zealand.

Statistics New Zealand, 2014c. Labour Market Statistics. Wellington: Statistics New Zealand.

Statistics New Zealand, 2014d. Consumers Price Index. Wellington: Statistics New Zealand.

Statistics New Zealand, 2014e. Building Consents Issued. Wellington: Statistics New Zealand.

Statistics New Zealand, 2014f. Census of Population and Dwellings. Wellington: Statistics New Zealand. 
Stokes, H.K., 1981. An examination of the productivity decline in the construction industry. Review of Economics and Statistics, 63(4), pp.495-502. doi: http://dx.doi.org/10.2307/1935844

Sweetman, A., 2002. "Working smarter: Education and productivity" pp.157-77.

United Kingdom Department of Business Enterprise and Regulatory Reform, 2008. Industry Performance Report 2008. London: Department of Business Enterprise and Regulatory Reform.

Van Dai Tran, 2010. Exploring Construction Productivity Statistics in New Zealand. Master of Engineering, Auckland University of Technology, Auckland.

Wang, Y.S., 1998. An Analysis of the Technical Efficiency in Hong Kong's Construction Industry. Unpublished PhD, University of Hong Kong, Hong Kong.

Wang, Y.S. and Chau, K.W., 1997. An evaluation of the technical efficiency of construction industry in Hong Kong using the DEA approach. Proceedings of ARCOM97 Conference, Cambridge, pp.690-701.

Wang, Y.S. and Chau, K.W., 2001. An assessment of the technical efficiency of construction firms in Hong Kong. International Journal of Construction Management, 1(1), pp.27-9. doi: http://dx.doi.org/10.1080/15623599.2001.10773021

Wang, H., Ye, G. and Yuan, H., 2010. An AHP/DEA methodology for assessing the productive efficiency in the construction industry. Management and Service Science 2010, International Conference, Wuhan, China, 24-26 August.

Worthington, A.C., 1999. Malmquist indices of productivity change in Australian financial services. Journal of International Financial Services, 9, pp.303-20. doi: http://dx.doi.org/10.1016/s1042-4431(99)00013-x

Xue, X., Shen, Q., Wang, Y. and Lu, J., 2008. Measuring the Productivity of the Construction Industry in China by Using DEA-Based Malmquist Productivity Indices. Journal of Construction Engineering and Management, 134(1), pp.64-71. doi: http://dx.doi.org/10.1061/(ASCE)0733-9364(2008)134:1(64) 


\section{Appendix: Productivity data items}

\begin{tabular}{|c|c|c|c|c|c|}
\hline & Output (engineering & Output & Input & Input & \\
\hline & Constant (2000) \$US 000' & square $\mathrm{M}$ & 000 & constant \$US m PPP & \\
\hline 1991 & 23262123 & $17,153,414$ & 546 & 13,525 & Aust \\
\hline 1992 & 19486606 & $20,375,631$ & 490 & 13,227 & Aust \\
\hline 1993 & 18802147 & $23,034,477$ & 506 & 13,270 & Aust \\
\hline 1994 & 19289477 & $24,826,519$ & 529 & 13,717 & Aust \\
\hline 1995 & 20411168 & $22,089,706$ & 561 & 14,033 & Aust \\
\hline 1996 & 22503311 & $18,065,562$ & 572 & 14,416 & Aust \\
\hline 1997 & 23594569 & $18,341,037$ & 559 & 14,124 & Aust \\
\hline 1998 & 26093580 & $21,846,292$ & 572 & 14,509 & Aust \\
\hline 1999 & 28209662 & $22,980,240$ & 606 & 14,912 & Aust \\
\hline 2000 & 28259454 & $26,967,485$ & 662 & 14,953 & Aust \\
\hline 2001 & 24579419 & $18,011,163$ & 642 & 14,487 & Aust \\
\hline 2002 & 25580217 & $26,580,384$ & 669 & 14,618 & Aust \\
\hline 2003 & 29801915 & $26,446,751$ & 688 & 14,751 & Aust \\
\hline 2004 & 32509066 & $28,528,167$ & 743 & 14,808 & Aust \\
\hline 2005 & 36468185 & $25,309,090$ & 797 & 15,081 & Aust \\
\hline 2006 & 42118923 & $25,151,373$ & 841 & 15,455 & Aust \\
\hline 2007 & 48893993 & $24,906,349$ & 906 & 15,886 & Aust \\
\hline 2008 & 53153317 & $25,711,866$ & 937 & 16,307 & Aust \\
\hline 2009 & 62533222 & $22,658,571$ & 959 & 17,859 & Aust \\
\hline 2010 & 61018995 & $22,587,000$ & 961 & 18,541 & Aust \\
\hline 1991 & $1,063,440$ & $2,434,001$ & 98 & 1,854 & NZ \\
\hline 1992 & $1,188,062$ & $2,677,553$ & 87 & 1,850 & NZ \\
\hline 1993 & $1,527,838$ & $2,972,945$ & 84 & 1,794 & NZ \\
\hline 1994 & $1,864,778$ & $3,793,952$ & 89 & 1,911 & NZ \\
\hline 1995 & $2,062,485$ & $3,603,994$ & 98 & 2,006 & $\mathrm{NZ}$ \\
\hline 1996 & $2,488,193$ & $3,919,354$ & 106 & 2,152 & NZ \\
\hline 1997 & $2,284,209$ & $4,063,689$ & 116 & 2,272 & NZ \\
\hline 1998 & $2,355,009$ & $3,258,167$ & 110 & 2,343 & NZ \\
\hline 1999 & $2,220,029$ & $4,301,973$ & 115 & 2,411 & NZ \\
\hline 2000 & $2,259,843$ & $3,494,261$ & 117 & 2,500 & NZ \\
\hline 2001 & $2,374,584$ & $3,663,299$ & 114 & 2,528 & NZ \\
\hline 2002 & $2,405,872$ & $4,797,807$ & 126 & 2,601 & NZ \\
\hline 2003 & $2,547,219$ & $5,523,797$ & 145 & 2,624 & $\mathrm{NZ}$ \\
\hline 2004 & $3,134,512$ & $5,664,582$ & 155 & 2,845 & NZ \\
\hline 2005 & $3,325,963$ & $4,965,783$ & 167 & 3,152 & NZ \\
\hline 2006 & $3,253,976$ & $4,967,159$ & 188 & 3,558 & NZ \\
\hline 2007 & $3,319,507$ & $5,021,487$ & 183 & 3,832 & NZ \\
\hline 2008 & $3,480,735$ & $3,633,232$ & 181 & 3,900 & NZ \\
\hline 2009 & $3,382,480$ & $2,818,783$ & 176 & 3,950 & NZ \\
\hline 2010 & $2,887,175$ & $3,113,124$ & 173 & 4,000 & NZ \\
\hline
\end{tabular}

